\title{
Acil Serviste Akut Karın Ağrısı Yönetimi: Cerrahi Ya Da Cerrahi Olmayan Karın Ağrıları
}

\section{Acute Abdominal Pain Management in the Emergency Department: Surgical or Non-Surgical Abdominal Pain}

\author{
${ }^{1}$ Nuray ASLAN, ${ }^{2}$ Ahmet BAYDIN, ${ }^{3}$ Murat YÜCEL, ${ }^{3}$ Yusuf YÜRÜMEZ, ${ }^{1}$ Bilge ERCAN \\ ${ }^{1}$ T.C. Sağlık Bakanlığı Sakarya Üniversitesi Eğitim ve Araştırma Hastanesi Acil Tıp Kliniği, Sakarya, Türkiye \\ ${ }^{2}$ Ondokuz Mayıs Üniversitesi Tıp Fakültesi Acil Tıp Anabilim Dalı, Samsun, Türkiye \\ ${ }^{3}$ Sakarya Üniversitesi Tıp Fakültesi Acil Tıp Anabilim Dalı, Sakarya, Türkiye
}

Nuray Aslan: https://orcid.org/0000-0001-8059-4862

Ahmet Baydın: https://orcid.org/0000-0003-4987-0878

Murat Yücel: https://orcid.org/0000-0003-0220-9230

Yusuf Yürümez: https://orcid.org/0000-0003-3917-9434

Bilge Ercan: https://orcid.org/0000-0003-1953-9025

\section{ÖZ}

Amaç: $\mathrm{Bu}$ çalışmada acil servise (AS) karın ağrısı nedeni ile başvuran hastalarda cerrahi (CNKA) ve cerrahi nedenli olmayan karın ağrılarının (CNOKA) karşılaştırılması amaçlanmıştır.

Materyal ve Metot: $\mathrm{Bu}$ çalışma prospektif olarak CNKA ve CNOKA olan 200 hasta ile gerçekleştirildi. Hastaların demografik özellikleri, klinik prezantasyonları, laboratuvar analizleri, görüntüleme yöntemleri, konsültasyonlar ve hasta bakım maliyetleri incelenmiştir.

Bulgular: Çalışma grubunun ortalama yaşı $50,8 \pm 20,1$ yıl ve hastaların \%52'sinin CNKA's1 olduğu tespit edildi. aldığ 1 , fizik muayenede hassasiyet-defans ve rebound birlikteliği ve ortalama $15,27 \pm 4,10 \mathrm{bin} / \mathrm{UL}$ ile beyaz küre yüksekliği tespit edildi. AS doktorlarınca öykü ve fizik muayene ile değerlendirme sonrasında konulan ön tanıları ve laboratuvar bulguları ile radyolojik görüntüleme yöntemleri sonrasında konulan son tanıların uyum yüzdesinin 71,7 olduğu saptandı. CNKA'lı olgularda, yaşlı hastalarda ve konsültasyon istenenlerde AS kalış süresi ve maliyetin yüksek olduğu saptand.

Sonuç: AS'lere karın ağrısı ile başvuran hastalarda anamnez ve fizik muayene mutlaka yapılmalı, sürecin hızlandırılması ve maliyetlerin azaltılmasına yönelik olarak özellikle CNKA düşünülen hastalarda ileri görüntüleme yöntemleri erken dönemde istenmelidir. Ancak bu sonucu destekleyecek ilave çalışmalar yapılmasına ihtiyaç vardır.

Anahtar Kelimeler: Acil servis,cerrahi,karın ağrısı, maliyet CNKA olgularda 75 yaş ve üzeri hastaların ilk sırada yer

\begin{abstract}
Objective: In this study, it was aimed to compare surgical (SAP) and non-surgical abdominal pain (NSAP) in patients admitted to the emergency department (ED) with abdominal pain.
\end{abstract}

Materials and Methods: This study was carried out prospectively with 200 patients with SAP and NSAP. The demographic characteristics, clinical presentations, laboratory analyzes, imaging methods, consultations and patient care costs of the patients were examined.

Results: The mean age of the study group was $50.8 \pm 20.1$ years and $52 \%$ of the patients were found to have SAP. In SAPcases, patients aged 75 years and above were in the first place, sensitivity-defense and rebound association and white blood cell elevation with an average of $15.27 \pm 4.10$ thousand / UL were detected in physical examination. It was determined that the percentage of agreement between the preliminary diagnoses and laboratory findings made after the history and physical examination and evaluation by the AS physicians and the final diagnoses made after the radiological imaging methods was 71.7. It was found that the duration of stay in the ED and the cost were high in cases with SAP, elderly patients and those who requested consultation.

Conclusion: Anamnesis and physical examination should definitely be done in patients who apply to $\mathrm{AD}$ with abdominal pain, and advanced imaging methods should be requested in the early period, especially in patients with SAP in order to accelerate the process and reduce costs. However, additional studies are needed to support this result.

Keywords: Abdominal pain, emergency service, surgery, cost

\section{Yayın Bilgisi / Article Info:}

Gönderi Tarihi/ Received: 29/12/2020

Kabul Tarihi/ Accepted: 03/03/2021

T.C. Sağlık Bakanlığı Sakarya Üniversitesi Eğitim Araştırma HasOnline Yayın Tarihi/ Published: 05/06/2021 tanesi Şirinevler, Adnan Menderes Cad. Sağlık Sok No:195, 54100 Adapazar1/Sakarya/TÜRKIYE

Tel: +90 5322574090

E-mail: nurayasanaslan@hotmail.com

Atıf / Cited: Aslan N ve ark. Acil Serviste Akut Karın Ağrısı Yönetimi: Cerrahi yada Cerrahi Olmayan Karın Ağrıları. Online Türk Sağllk Bilimleri Dergisi 2021;6(2):224-235. doi: 10.26453/otjhs.849297 


\section{GÍRIŞ}

Akut karın ağrısı; travma dışı nedenlere bağlı gelişen, nedeni bilinmeyen ve bir haftadan daha kısa süredir var olan, karın içi veya karın dışı organları ilgilendiren hastalıkların seyri sırasında ortaya çıkan bir semptomdur. Acil Servis (AS) başvurularının yaklaşık olarak \%5-10'unu oluşturur. ${ }^{1,2}$ Yapılan çalışmalar, hastaların yaklaşık \%31-53' 'ünde hiçbir patoloji bulunamazken, \%24-47 hastada ise hastaneye yatışı gerektiren cerrahi nedenler saptanabilir. ${ }^{3-5}$ Diğer taraftan AS'ten taburcu edilen hastaların yaklaşık olarak \%3'ünün takip eden ilk üç hafta içerisinde tekrar tıbbi müdahaleye gereksinim duydukları da tespit edilmiştir. ${ }^{6} \mathrm{Bu}$ yüzden akut karın ağrısı şikâyeti ile AS'e başvuran bir hastanın hızlı bir şekilde değerlendirilerek tanısının konması ve tedavisinin düzenlenmesi son derece önemlidir. ${ }^{6-8}$

Akut karın ağrılı hastada tanı ve tedavinin planlanmasında öykü ve fizik muayene esas olmakla birlikte, tanının doğrulanması ve tedavinin zamanlaması için tetkik ve görüntüleme yöntemlerine gereksinim duyulmaktadır. Ancak literatüre bakıldığında görüntüleme yöntemlerinin hangi hastada kullanılması gerektiğine dair bilgiler net olmayıp hekime ve hastaneye göre değişebilmektedir. ${ }^{1,7-9}$ Görüntüleme yöntemlerinin fazla kullanımı hastanın maruz kaldığ1 radyasyonu ve maliyetleri arttırırken, yetersiz kullanımı ise tanı ve tedavinin gecikmesinin yanı sıra mortalite ve morbiditenin artmasına neden olmaktadır. $^{7,8}$

Akut karın ağrılı hastaların AS yönetimine etki eden faktörlerden birisi de konsültasyonlardır. Konsültasyonların uygun şekilde yürütülmeleri ve ivedi olarak neticelendirilmeleri gerekir. Aksi halde AS'teki kalış süreleri, hasta bakım maliyetlerinde ve hasta memnuniyetsizliğinde artışa neden olabilir. ${ }^{11}$

Bu çalışmada akut karın ağrısı nedeni ile AS'e başvuran hastaların demografik özellikleri, klinik prezantasyonları, laboratuvar analizleri, görüntüleme yöntemleri, konsültasyonlar ve hasta bakım maliyetleri açısından incelenerek cerrahi ve cerrahi olmayan karın ağrıları açısından bir değerlendirme yapılması amaçlanmıştır.

\section{MATERYAL VE METOT}

Çalışma Dizaynı ve Etik: Bu çalışma bir Samsun Ondokuz Mayıs Üniversitesi Uygulama ve Araştırma Hastanesi AS'ine başvuran 15538 hastadan travma dışı karın ağrısı yakınmasıyla gelen ve çalışmaya katılmayı kabul eden 16 yaş üzerindeki 200 olgunun yerel etik kuruldan izin alınarak (Tarih:30.08.2006, karar no:294) ve Helsinki Deklarasyonuna uygun olarak prospektif olarak değerlendirilmesi ile gerçekleştirildi.

Hasta seçimi: Hastalar öykü, fizik muayene, laboratuvar değerleri, görüntüleme tetkikleri ve gerekli görülmesi durumunda yapılan konsültasyon sonuçlarına göre Ertekin ve $\operatorname{ark}^{8}$ tarafindan yapılan sınıflamaya göre Cerrahi Nedenli (CNKA) ve Cerrahi Nedenli Olmayan Karın Ağrıları (CNOKA) olarak iki gruba ayrıldı (Tablo 1). Travma ile ilişkili karın ağrılı hastalar, 16 yaş altı hastalar, bağışıklık sistemi baskı altında olan hastalar ve ilaç bağımlısı olan hastalar ise çalışma kapsamı dışında tutuldu.

Çalışma kapsamında hastaların demografik özellikleri, özgeçmişleri, vital bulguları, fizik muayene bulgular1, laboratuvar incelemeleri (hemogram), yapılan görüntülemeler (akciğer grafisi, ayakta direk karın grafisi-ADKG; direk üriner sistem grafisiDÜSG; bilgisayarlı tomografi-BT; ultrasonografiUSG), konsültasyonlar, AS'te kalış süreleri, istenilen tetkiklerin toplam maliyetleri (çalışma dönemindeki birim fiyatları dikkate alınd1), son tanılar ve tanı sonrası akıbetleri önceden hazırlanmış kayıt formuna kaydedildi. Ayrıca hastalar ön tanı ile son tanı arasındaki uyum açısından da karşılaştırıldı.

Ístatistiksel Yöntem: Hastalardan elde edilen veriler SPSS (Statistical Package for Social Science) istatistik programı kullanılarak analiz edildi. Cerrahi nedenli ve CNOKA; yaş grubu, cinsiyet, özgeçmiş, eşlik eden semptomlar, vital bulgular, fizik muayene bulguları, beyaz küre sayıları, AS'te takip süreleri, istenilen tetkik maliyetleri, istenilen radyolojik görüntüleme yöntemleri, konsültasyonlar ve AS'teki tanı sonrası akıbetleri açısından karşılaştırıldı. Ayrıca bu iki grupta AS doktorunun ön tanıları ile son tanılar arasındaki korelasyon da incelendi. Olgular arasındaki incelenen sürekli değişkenlerin (toplam maliyet, AS izlem süresi gibi) normal dağılıma uygunluk kontrolü ShapiroWilk testi ile yapıldı. Normal dağılıma uymayan gruplar arası karşılaştırmalarda ise non-parametrik Kruskal-Wallis ve MannWhitney U testi uyguland1. Kategorik verilerin değerlendirmesinde Chi-Square testi kullanıldı. Karş1laştırma yapılan gruplarda beklenen hücre değerleri 5 'ten küçük olduğunda Fisher's-Exact testi uygulandı. Özellikler arasındaki ilişkiler Spearmanın Korelasyon Testi kullanılarak hesaplandı. Tanımlayıcı istatistik olarak Ortalama \pm Standart Sapma (Ort \pm SD) yanında ortanca (min-max) değerleri birlikte verildi. İstatistiksel önemlilik düzeyi olarak $p<0,05$ esas alındı. 


\section{BULGULAR}

Çalışma kapsamında değerlendirmeye alınan karın ağrılı hastaların AS başvuru sayısına oranı \%1,4 olarak tespit edilmiş olup 104'ü (\%52) kadın, 96's1 (\%48) erkek, kadın erkek oranı 1,08 ve yaş ortala-

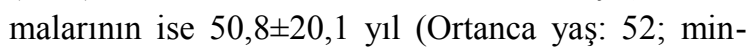
max: 18-87) olduğu saptand1.

Cerrahi ve Cerrahi Nedenli Olmayan Karın Ăgrılı Hastalar Karşılaştırıldığında Yaş ve cinsiyet: Hastalar CNKA ve CNOKA olarak ikiye ayrıldığında: 104 (\%52) hastanın CNKA ve 96 (\%48) hastanın ise CNOKA kapsamına girdiği belirlendi, hasta sayısına göre iki grup arasında istatistiksel olarak anlamlı fark tesbit edildi $(p<0,001)$. Yaşlara göre dağılım incelendiğinde; CNKA hastalarda 75 yaş ve üzeri hastaların, CNOKA hastalarda ise 16-25 yaş grubundaki hastaların ilk sırada yer aldığı saptandı (Tablo 2, $\mathrm{p}<0,05)$.

Vital Bulgular: Hastaların başvuru anında ölçülen vital bulguları karşılaştırıldığında CNKA hastalarda vücut sıcaklığı, nabız sayısı ve solunum sayısının daha yüksek olduğu ve hipertansif seyrettiği saptanmış olup, tüm parametreler için istatistiksel olarak anlamlı bir fark tespit edildi (Tablo 2, $\mathrm{p}<0,001$, $\mathrm{p}<0,01)$.

Fizik Muayene: CNOKA olan grupta en s1k batında izole hassasiyet varlığı, CNKA grupta ise en sik hassasiyet-defans ve rebound birlikteliği olduğu dikkat çekti (Tablo 2). Gruplar arası karşılaştırmada ise; hassasiyet ve rebound birlikteliği için aralarında istatistiksel olarak anlamlı bir fark tespit edilmezken $(p>0,05)$ diğer muayene bulgularında istatistiksel olarak anlamlı fark tespit edildi $(\mathrm{p}<0,05)$.

Hemogram: CNKA tanı alan olguların 104'ünde, CNOKA tanısı alan olguların ise 93'ünde olmak üzere toplam 197 olguda tam kan sayımı bakıldığı, ortalama beyaz küre düzeyleri incelendiğinde CNKA alan olgularda ortalama 15,27 $\pm 4,10$ (ortanca: 14,65; min-max: 7,9-29,8) bin/UL iken, CNOKA alan olgularda ortalama 12,18 $\pm 2,82$ (ortanca: 12,9; min-max: 5,8-18,30) bin/uL idi. Yapılan istatistiksel çalışmada anlamlı bir fark elde edildi (Tablo 2, $\mathrm{p}<0,001)$.

Görüntüleme Yöntemleri: Hastaların \%2'sinde herhangi bir görüntülemenin yapılmadığı ve bu hasta grubunun tamamının CNOKA'lı grupta yer aldığı tespit edildi (Tablo 3). İstenilen görüntüleme yöntemleri gruplar arasında karşılaştırıldığında CNOKA grupta sadece DG, CNKA alan grupta ise DG-USG birlikte isteminin en sık olduğu ve tüm görüntüleme yöntemleri için gruplar arasında istatistiksel olarak anlamlı fark olduğu tespit edildi $(\mathrm{p}<0,05)$.
İstenilen görüntüleme yöntemleri tanı bazlı değerlendirildiğinde ise; CNKA hastalarda USG'nin en s1k akut kolesistit ve mekanik barsak tıkanıklığı düşünülen hastalarda $(n=26, \% 19,0)$ istendiği, CNOKA tanısı alan hastalarda ise USG'nin en s1k ürolitiyazis düşünülen hastalarda $(n=14, \% 10,2)$ istendiği belirlendi. BT'nin ise CNKA hastalarda en s1k mekanik barsak tıkanıklığı düşünülen hastalarda $(n=10, \%$ 19,2) istendiği, CNOKA grupta ise pankreatit düşünülen hastalarda $(n=6, \% 11,5)$ istendiği tespit edildi.

Konsültasyon: Konsültasyon dağılımı incelendiğinde CNKA grupta konsültasyon istem sayısının istatistiksel olarak anlamlı yüksek olduğu tespit edildi (Tablo 3, p<0,001).

Son Tanı: Hastaların öykü, fizik muayene, laboratuvar bulguları ve radyolojik görüntüleme yöntemleri sonrasında belirlenen son tanıları incelendiğinde; CNKA 104 olgu arasında en sık sebebin mekanik barsak obstrüksiyonu $(\mathrm{n}=35, \% 33,6)$ CNOKA 96 olgu arasında ise en sık başvuru sebebinin ürolitiyazis $(\mathrm{n}=27, \% 28,1)$ olduğu saptandı (Sekil 1).

Acil servise başvuran 200 karın ağrılı hastanın, AS doktorlarınca öykü ve fizik muayene ile değerlendirme sonrasında konulan ön tanıları ve laboratuvar bulguları ile radyolojik görüntüleme yöntemleri sonrasında konulan son tanıların uyum yüzdesinin 71,7 olduğu saptand1.

Acil Servis Takip Süresi ve Maliyet: Olguların AS'te takip süresi ve istenilen tetkiklerin toplam maliyeti incelendiğinde CNKA olguların AS takip sürelerinin ve istenilen tetkiklerin toplam maliyetinin CNOKA olgulara oranla istatistiksel olarak anlamlı yüksek olduğu tespit edildi (Tablo 3, p<0,05). Hastalarda maliyet ve AS takip süresinin konsültasyon istenen ve istenmeyen olgulardaki dağılımı incelendiğinde konsültasyon istenen olgularda süre ve maliyet istatistiksel olarak anlamlı yüksek tespit edildi (Tablo 3, $\mathrm{p}<0,001$ ).

Olguların son tanılarına göre AS takip süreleri ve tetkik toplam maliyeti ayrı ayrı incelendiğinde CNKA olgularda mesenterik iskemi tanısı alan olgular $(n=4)$ ortalama $14,8 \pm 12,0$ (ortanca saat 16 ; minmax: 2-25) saat ile en uzun süre AS'te kalan hasta grubu iken, abdominal aort diseksiyonu tanısı alan tek olgu dört saat ile AS'te en kisa süre kalan hasta idi. Yine aynı grupta mesenterik iskemi tanısı alan olgular $(n=4)$ ortalama $306,3 \pm 130,8$ (ortanca tutar 360,7; min-max: 111,7-391,9) TL ile en yüksek toplam maliyete sahipken, akut kolesistitli olgular $(n=30)$ ortalama $125,4 \pm 92,4$ (ortanca tutar 65,6 ; min -max: 55,4-395,0) TL ile en düşük toplam maliyete 
sahipti (Tablo 4).

CNOKA grupta pankreatit tanisı alanlar ortalama $10,6 \pm 6,8$ (ortanca 8;3-24) saat ile en uzun süre AS'te kalan hasta grubu iken pankreatit tanısı alan olgular $(n=18)$ ortalama $189,4 \pm 79,5$ (ortanca 202,2; 54,4$356,6)$ TL ile en yüksek toplam maliyete ve gastroenterit tanısı alan olgular ortalama 75,6 4132,3 (ortanca 19,9; 3,9-311,9) TL ile en düşük toplam maliyete sahipti (Tablo 4).

Olguların yaş gruplarına göre maliyet dağılımı incelendiğinde CNKA grupta yaş grubu ile maliyet arasında istatistiksel olarak anlamlı bir ilişki tespit edilemezken $(r=0,02, p>0,05)$, CNOKA grupta yaş arttıkça toplam maliyetin arttığ istatistiksel olarak anlamlı bir ilişki ile tespit edildi (Tablo 3, $\mathrm{r}=0,355$, $\mathrm{p}<0,05$ ).

200 hastanın AS'te değerlendirmesi tamamlandıktan sonra $88(\% 44)$ hastanın tedavilerinin devamı için ilgili servislere yatırıldığını belirlendi. Hastaların 32 (\%16)'sının farklı nedenlerle başka hastanelere gönderildiği, sekiz (\%4)'ünün tedaviyi reddederek kendi isteği ile hastaneden ayrıldığı ve üç $(\% 1,5)$ hastanın ise AS'te tetkik ve tedavisi devam ederken öldüğü saptandı. CNKA hastalarının $71(\% 68,3)$ 'ü için yatış yapılırken, CNOKA hastaların $17(\% 17,7)$ 'sinin yatırıldığı saptandı. İki grup arasında servislere yatış açısından istatistiksel olarak anlamı bir fark tespit edildi (Tablo 3, $\mathrm{p}<0,001$ ).

\section{TARTIŞMA VE SONUÇ}

Acil servis başvurularının sık nedenlerinden olan karın ağrısı benign durumlardan hayatı tehdit edici durumlara kadar uzanan geniş bir yelpazeye sahip olduğundan hızlı ve uygun hasta yönetimini gerektirir. ${ }^{10}$ Ancak sebebin ortaya konması ve tedavisi çeşitli nedenlerden dolayı zor olduğundan genellikle çok sayıda gereksiz test yapılmasına, AS'te kalış sürelerinde artışa, gereksiz cerrahi girişimlere ve artan maliyetlere neden olmaktadır. ${ }^{7}$

Hastaların değerlendirilmesindeki temel yaklaşım ağrının cerrahi nedenli olup olmadığının ortaya konmasıdır. Bu konuda yapılmış olan çalışmalarda iki grup arasında belirgin bir farklılık olmamakla birlikte CNKA'nın daha fazla olduğu rapor edilmiştir. $^{4,5,8,12}$ Al-Mulhim ve Lameris ve ark. tarafindan travma dışı karın ağrılı hastalarda yapılan her iki çalışmada da bu oran \%65 olarak rapor edilmiştir., Bizim çalışmamızda da CNKA'lı hasta sayısının \% 52 ile daha fazla olduğu saptanmış olup, bu sonuç literatür ile uyumludur.

Hastaların yaş dağılımları incelendiğinde değişken rakamların ortaya çıktığı gözlenmekle birlikte \%25'inden fazlasının 50 yaş üstü olduğu ortaya konmuştur. ${ }^{13-15}$ Yaş faktörünü önemli kıllan şey, yaşlı popülasyonda hayatı tehdit eden durumların gençlere oranla daha yüksek olmasıdır. ${ }^{11,14}$ Nitekim genç popülasyon ile karşılaştırıldığında yaşlı hasta grubunda CNKA'nın görülme olasılığı daha fazladır. ${ }^{13,14} \mathrm{Bu}$ sonuç bizim çalışma sonuçlarımız ile de uyumludur. Vital bulgulara bakıldığında; ateş, nabız, solunum sayısı ve kan basıncinın CNKA'lı hastalarda daha yüksek olduğu saptanmıştır. Bu sonucu destekleyen literatürde çok sayıda çalışmanın olduğu görülmektedir. ${ }^{7,16,17}$ Ancak Burg ve ark. yapmış oldukları bir çalışmada, vital parametrelerdeki patolojik değişikliklerin altta cerrahi nedenli patoloji olma olasılığını artırdığını bildirmişlerdir. ${ }^{18}$

Klinik bilgilerin büyük bir kısmı fizik muayene sırasında yapılan palpasyon ile elde edilir. Palpasyonda tespit edilen hassasiyet lokalizasyonuna göre ayırıcı tanıya gidilmesine yardımcı olurken, rebound varlığ ise çok az ek bilgi sağlar. ${ }^{19} \mathrm{Bu}$ konudaki literatüre bakıldığında; CNKA hastalar için defans varlığının belirleyici faktörler arasında yer aldığ 1 , rebound varlığının ise peritonitin klinik kriterlerinden sayılmasına rağmen tanısal yararlılığının düşük olduğundan bahsedilmektedir. ${ }^{1,11,19-21}$ Nitekim Staniland ve ark. yaptıkları bir çalışmada, peptik ülser perforasyonlu hastaların yalnızca \%39'unda rebound tespit etmişlerdir. ${ }^{20}$ Bizim çalışma sonuçları literatürle uyumlu olup, batın palpasyonunda defans varlığının CNKA hastalarına, hassasiyet varlığının ise CNOKA hastalarına sıklıkla eşlik edebileceğini söylenebilir.

Pratik uygulamada tam kan sayımı en sik istenen tetkiklerdendir. Yapılan farklı çalışmalarda, çalışmamızla uyumlu olarak CNKA hasta grubunda beyaz küre sayısının diğer gruba göre anlamlı olarak yüksek bulunduğu ve tanıda dikkate alınması gerektiği bildirilmiştir., ${ }^{7,22}$ Ancak bu sonuç hastalık olasılığını gözden geçirmek için yeterince güçlü değere (LR) sahip değildir. ${ }^{19}$

Görüntüleme yöntemlerinin seçimi de yine ayrı bir muammadır. Seçim yaparken ağrının lokalizasyonu, hastanın yaşı, cinsiyeti ve laboratuvar parametreleri dikkate alınmalıdır. ${ }^{7}$ Literatürde yıllardır karın ağrılı hastalarda ilk görüntüleme yöntemi olarak DG önerilmekte iken, yapılmış çok sayıdaki güncel çalışmada üçlü DG'lerin (akciğer grafisi, ADKG ve DÜSG) dahi duyarlılığın düşük olduğu ve ilk görüntüleme yöntemi olarak BT'nin daha etkin olduğu bildirilmektedir. ${ }^{7,10}$ Ultrasonografi, çalışmamızda \%70,5 oranıyla ikinci en sık istenilen görüntüleme yöntemi olmasına rağmen, hastaların yalnızca $\% 5,5$ 'inde tek başına tanı koydurucu olduğu saptanmıştır. Lameris 
ve ark. ise, hastalarda istenen USG sonrası sonuç negatif gelirse veya sonuç vermez ise çekilecek BT'nin daha yüksek sensitivite değerine sahip olduğunu bildirmişlerdir (şartlı BT stratejisi). ${ }^{9}$

Acil servise karın ağrısı ile başvuran hastalara konulan son tanılar, çalışmanın yapıldığı yer ve yaş aralıklarına bağlı olarak değişkenlik gösterebilir. Nitekim literatürde CNKA içinde en sık olarak akut apandisitin, CNOKA'nda ise en s1k nonspesifik karın ağrısının (NSKA) ilk sıralarda aldığı görülmektedir. ${ }^{1,11}$ Bizim çalışmamızda ise, CNKA içinde en sık olarak

mekanik barsak obstrüksiyonu, CNOKA'nda ise en sık ürolitiazisin ilk sıralarda aldığı görülmektedir. $\mathrm{Bu}$ sonuç yukarıda izah edilen nedenlerden dolayı farklı çıkmış görünmektedir.

Günümüzdeki mevcut teknolojik gelişmelere rağmen hiçbir görüntüleme yöntemi ve laboratuvar testi anamnez ve fizik muayenenin yerini almamalıdır. Tetkik ve görüntüleme yöntemleri anamnez ve fizik muayene bulgularına göre konulan tanının desteklenmesi veya dışlanması için yapılmalıdır. ${ }^{7,11,23} \mathrm{Bi}$ zim çalışma sonuçlarına bakıldığında; 200 karın ağrılı hastada, AS doktorlarının öykü ve fizik muayene ile değerlendirmesi sonucunda koyduğu ön tanıların, laboratuvar ve radyolojik görüntüleme yöntemleri sonrasında ortaya çıkan son tanılarla karşılaştırıldığında \%71,7 oranında doğru olduğu saptamıştır. Bu sonuç anamnez ve fizik muayenenin önemini bir kez daha ortaya koymaktadır.

CNKA grupta hayatı tehdit edebilecek karın içi patolojilerin görülme olasılığı hekimleri tanı ve ayırıcı tanı için daha fazla tetkik istemeye zorlamaktadır. $\mathrm{Bu}$ durum maliyet artışına ve AS izlem süresinin uzamasına neden olmaktadır. Karın ağrısı nedenlerinin alt gruplarında AS izlem süresi ve maliyet karşılaştırıldığında, bizim çalışma sonuçlarımız ile Aygencel ve ark. yaptıkları çalışma sonuçları benzerlik göstermektedir. Her iki çalışmada da CNKA hastalarda diğer gruba oranla maliyetler daha yüksek, AS izlem süreleri ise daha uzun bulunmuştur. ${ }^{11}$ Cerrahi ve CNOKA hasta gruplarında son tanılara göre AS izlem süresi ve maliyet incelendiğinde CNKA hasta grubunda mesenter iskemi, CNOKA hasta grubunda ise pankreatit tanısı alan hastalar AS'te en uzun süre kalan ve en yüksek maliyete sahip oldukları gözlenmiştir. $\mathrm{Bu}$ durum mesenter iskeminin ek hastalıkları olan yaşlı popülasyonda sıklıkla görülüyor olmasına, fizik muayene bulgularının geç ortaya çıkması ve silik seyretmesine, şüphelenilen olgularda çekilen IV + oral kontrastlı BT gibi uzun vakit alan görüntüleme yöntemi ile tanısı- nın konulabilmesine bağlı olabilir. ${ }^{14,24}$ Yine aynı şekilde tipik öyküye rağmen fizik muayene bulgularının silik olması, pankreasın retroperitoneal bir organ olması nedeni ile USG gibi daha ucuz bir görüntüleme yöntemi ile her zaman tanının konulamamaS1, tanısında IV + oral kontrastlı BT ve ek kan tetkikleri gerekliliği AS izlem süresini ve maliyeti arttırmaktadır. 7,11,14

Karın ağrısı nedenlerinin alt gruplarında AS takip süresine göre tetkiklerin ortaya çıkardığı toplam maliyet incelendiğinde, CNKA hastalarda süre ile maliyet arasında ters ilişki olduğu görülmektedir. $\mathrm{Bu}$ durumun; CNKA hasta grubunda cerrahi girişim gerektiren patoloji olasılığının ve yaşlı grubun fazla olmasından ayrıca tanı ve tedavideki gecikmenin ise morbidite ve mortalitede artmaya neden olabileceği düşüncesi ile görüntüleme yöntemlerine sıklıkla başvurulmasından kaynakladığını kanaatindeyiz. Nitekim bu konuda bizim düşüncemizi destekleyen literatürde çok sayıda çalışmanın olduğu görülmektedir. ${ }^{11,15} \mathrm{Bu}$ çalışmalarda, görüntüleme yöntemlerinin tanısal süreçlerde potansiyel cerrahi girişim gerektiren durumların uygun şekilde ayırımında yararlı olduğu, hastanede kalış süresi ve mortalite ise azalttığı rapor edilmektedir. ${ }^{11,25,26}$

Yaş gruplarına bakıldığında; yaş ile AS izlem süresi arasında ayrica CNKA hasta grubunda maliyet ile yaş grupları arasında istatistiksel olarak anlamlı bir ilişki bulunmazken, CNOKA hasta grubunda yaş artışı ile maliyetin arttığı görülmektedir. Bu konudaki literatüre bakıldığında; yaşlı hastalardaki kliniğin geç oturması, ek nonspesifik şikâyetler, ek hastalıklar, kendilerini net ifade edememe ve muayene bulguları ve laboratuvar parametrelerinin silik olması bu yaş grubunda tanıya gidilmesini zorlaştırdığı ifade edilmektedir. ${ }^{14,15}$ Özellikle CNOKA hastalarda tanıya ulaşmak için yaş artışı ile birlikte istenen tetkik ve tahlillerin artması bizim çalışmamızda olduğu gibi maliyetleri yukarı çekmektedir.

Sonuç olarak AS'lere karın ağrısı ile başvuran hastalarda anamnez ve fizik muayene mutlaka yapılmalı, sürecin hızlandırılması ve maliyetlerin azaltılmasına yönelik olarak özellikle CNKA düşünülen hastalarda ileri görüntüleme yöntemleri erken dönemde istenmelidir. Ancak bu sonucu destekleyecek ilave çalışmalar yapılmasına ihtiyaç vardır.

Etik Komite Onayı: Bu çalışma için Samsun Ondokuz Mayıs Üniversitesi Uygulama ve Araştırma Hastanesi Etik Kurulu'ndan onay alınmıştır (Tarih:30.08.2006, karar no:294). 
Çıkar Çatışması: Yazarlar çıkar çatışması bildirmemektedir.

Yazar Katkıları: Fikir - AB, NA; Denetleme - YY; Veri toplanması ve/veya işlemesi - NA; Analiz ve/ veya yorum - NA, MY, BE; Yazıyı yazan - NA, YY.

Hakem değerlendirmesi: D1ş bağımsız.

\section{KAYNAKLAR}

1. Natesan S, Lee J. Evidence-based medicine approach to abdominal pain. Emerg Med Clin North Am. 2016;34(2):165-190. doi:10.1016/ j.emc.2015.12.008

2. de Burlet K, Lam A. Acute abdominal painchanges in the way we assess it over a decade. $\mathrm{N}$ Z Med J. 2017;130:39-44.

3. Kachalia A, Gandhi TK. Missed and delayed diagnoses in the emergency department: a study of closed malpractice claims from 4 liability insurers. Ann Emerg Med. 2007;49(2):196-205.

4. Kacprzyk A, Stefura T, Chłopaś K, etc al. Analysis of readmissions to the emergency department among patients presenting with abdominal pain. BMC Emerg Med. 2020;12;20 (1):37. doi:10.1186/s12873-020-00334-x

5. Chanana L, Jegaraj AM, Kalyaniwala, etc al. Clinical profile of non-traumatic acute abdominal pain presenting to an adult emergency department. J Family Med Prim Care. 2015;4(3):422427. doi:10.4103/2249-4863.161344

6. Cartwright SL, Knudson MP. Evaluation of acute abdominal pain in adults. Am Family Physician. 2008;77(7):971-978.

7. Lameris W, van Randen A. Imaging strategies for detection of urgent conditions in patients with acute abdominal pain: Diagnostic accuracy study. BMJ. 2009;338:b2431. doi:10.1136/bmj.b2431

8. Lameris W, van Randen A. Optimization of diagnostic imaging use in patients with acute abdominal pain OPTIMA: Design and rationale. BMC Emerg Med. 2007;7:9-15. doi:10.1186/1471227X-7-9

9. Ertekin C, Güloğlu R, Taviloğlu K. Akut karın hastasına yaklaşım: In: Acil Cerrahi, ed. Kalaycı G. 2nd ed. Nobel Tıp Kitabevi; 2002;195-216.

10. Abdolrazaghnejad A, Rajabpour-Sanati A. The role of ultrasonography in patients referring to the emergency department with acute abdominal pain. Adv J Emerg Med. 2019;3(4):e43. doi:10.22114/ajem.v0i0.152
11. Aygencel G, Y1lmaz U. Acil serviste karın ağrısını değerlendirmenin maliyeti. Gazi Medical Journal. 2009:20(1):7-12.

12.Al-Mulhim AA. Emergency general surgical admission. Prospective institutional experience in non-traumatic acute abdomen: implications for education, training and service. Sauudi Med J. 2006;27(11):1674-1683.

13. Lyon C, Clark DC. Diagnosis of acute abdominal pain in older patients. American Family Physician. 2006;74:1537-1544.

14. Leuthauser A, McVane B. Abdominal pain in the geriatric patient. Emerg Med Clin North Am. 2016;34(2):363-375. doi:10.1016/j.emc.2015. 12.009

15. Magidson PD, Martinez JP. Abdominal pain in the geriatric patient. Emerg Med Clin North Am. 2016;34(3):559-574. doi:10.1016/j.emc.2016. 04.008

16. Laurell H, Hansson LE, Gunnarsson U. Acute abdominal pain among elderly patients. Gerontology. 2006;52:339-344.

17. Abbas SM, Smithers T, Truter E. What clinical and laboratory parameters determine significant intra abdominal pathology for patients assessed in hospital with acute abdominal pain? World Journal of Emergency Surgery. 2007;2:26-30. doi:10.1186/1749-7922-2-26

18. Burg MD, Francis L. Acute abdominal pain in the elderly. Ann Emerg Med. 1990;19(12):13831389. doi:10.1016/s0196-0644(05)82602-2

19. Masneri D.A, O’Brein. Acute abdominal pain. In: Emergency Medicin: A Comprehensive Study Guide, ed. Tintinalli E.J, 9th ed. New York: McGraw-Hill; 2019:473-481.

20. Staniland JR, Ditchburn J, de Dombal FT. Clinical presentation of the acute abdomen: Study of 600 patients. Br Med J. 1972;3:393-398.

21. Besinger B,Stehman C.R. Pankreatitis and cholecystitits. In: Emergency Medicine: A Comprehensive Study Guide, ed. Tintinnalli JE, John Ma. O, Yealy M.D. 9th ed. New York: McGrawHill; 2019:508-516.

22. Gans SL, Atema JJ, Stoker J, ve ark. C-reactive protein and white blood cell count as triage test between urgent and nonurgent conditions in 2961 patients with acute abdominal pain. Medicine (Baltimore). 2015;94(9):e569. doi:10.1097/ MD.0000000000000569

23. Gans SL, Pols MA, Stoker J, et al. Guideline fort he diagnostic pathway in patients with acute ab- 
dominal pain. Dig Surg. 2015:32(1):23-31. doi: $10.1159 / 000371583$

24. Flasar MH, Cross R, Goldberg E. Acute abdominal pain. Prim Care: Clin in Office Pract. 2006;33:659-684. doi:10.1016/j.pop.2006.06.004

25. Özgüç H, Çakın N. Akut nonspesifik karın ağrılı olguların 1 yıllık prognozları, semptom ve bulgularının tanısal doğruluğu. Ulusal Travma Acil Cerrahi Dergisi. 2008;14:118-124.

26. Claessen JJM, van Es JM, Boermeester MA. Abdominal pain. Ned Tijdschr Geneeskd. 2019;20;163:D3052. 
Tablo 1. Akut Karın Tablosu Meydana Getiren Başlıca Hastalıklar. ${ }^{8}$

\begin{tabular}{|l|l|l|l|}
\hline Cerrahi Nedenli Karın Ağrıları & \multicolumn{2}{|c|}{ Cerrahi Nedenli Olmayan Karın Ağrıları } \\
\hline & \multicolumn{2}{|c|}{ Medikal Patolojiler } & \multicolumn{1}{|c|}{ Karın Dışı Patoloji- } \\
ler
\end{tabular}


Tablo 2. Hastalara ilişkin demografik veriler, vital bulgular, özgeçmiş, muayene bulguları ve laboratuvar değerleri.

\begin{tabular}{|c|c|c|c|c|}
\hline & & $\begin{array}{c}\text { CNKA } \\
(\mathrm{n}=104, \% \\
52,0) \\
\end{array}$ & $\begin{array}{c}\text { CNOKA } \\
(\mathrm{n}=96, \% 48,0)\end{array}$ & $P$ \\
\hline \multirow[t]{2}{*}{ YASS } & Ortanca (min-max) & $58,5(18-87)$ & $39(18-83)$ & \multirow[t]{2}{*}{$<0,01$} \\
\hline & $\mathrm{O} \pm \mathrm{SD}$ & $57,6 \pm 18,5$ & $43,5 \pm 19,3$ & \\
\hline \multirow[t]{7}{*}{ YAŞ GRUPLARI } & $16-25(n=28, \% 14)$ & $7(\% 6,7)$ & $21(\% 21,9)$ & $<0,05$ \\
\hline & $26-35(\mathrm{n}=27, \% 13,5)$ & $8(\% 7,7)$ & $19(\% 19,8)$ & $<0,05$ \\
\hline & $36-45(\mathrm{n}=29, \% 14,5)$ & $11(\% 10,6)$ & $18(\% 18,8)$ & $>0,05$ \\
\hline & $46-55(n=24, \% 12,0)$ & $14(\% 13,5)$ & $10(\% 10,4)$ & $>0,05$ \\
\hline & $56-65(\mathrm{n}=32, \% 16,0)$ & $21(\% 20,2)$ & $11(\% 11,5)$ & $<0,05$ \\
\hline & $66-75(\mathrm{n}=29, \% 14,5)$ & $19(\% 18,3)$ & $10(\% 10,4)$ & $<0,05$ \\
\hline & $>75(\mathrm{n}=31, \% 15,5)$ & $24(\% 23,1)$ & $7(\% 7,3)$ & $<0,05$ \\
\hline \multicolumn{5}{|c|}{ VITAL BULGULAR } \\
\hline \multirow[t]{2}{*}{ Vücut sıcaklığg $\left({ }^{\circ} \mathrm{C}\right)$} & Ortanca (min-max) & $\begin{array}{c}37,1(35,0- \\
39,8)\end{array}$ & $\begin{array}{c}36,9(36,0- \\
39,0)\end{array}$ & \multirow[t]{2}{*}{$<0,001$} \\
\hline & $\mathrm{O} \pm \mathrm{SD}$ & $37,4 \pm 0.9$ & $36,9 \pm 0,5$ & \\
\hline \multirow[t]{2}{*}{ Nabız (atım/dk) } & Ortanca (min-max) & $22(19-30)$ & $70(59-95)$ & \multirow[t]{2}{*}{$<0,001$} \\
\hline & $\mathrm{O} \pm \mathrm{SD}$ & $78,1 \pm 11,3$ & $71,7 \pm 8,2$ & \\
\hline \multirow[t]{2}{*}{ Solunum sayısı (sol/dk) } & Ortanca (min-max) & $22(19-30)$ & $22(19-25)$ & \multirow[t]{2}{*}{$<0,001$} \\
\hline & $\mathrm{O} \pm \mathrm{SD}$ & $22,4 \pm 2,6$ & $21,4 \pm 1,7$ & \\
\hline \multirow[t]{2}{*}{ Sistolik basınç (mmHg) } & Ortanca (min-max) & $140(90-190)$ & $125(100-90)$ & \multirow[t]{2}{*}{$<0,01$} \\
\hline & $\mathrm{O} \pm \mathrm{SD}$ & $140,3 \pm 20,7$ & $132,2 \pm 22,3$ & \\
\hline \multirow{2}{*}{$\begin{array}{l}\text { Diastolik basınç } \\
\text { (mmHg) }\end{array}$} & Ortanca (min-max) & $90(60-140)$ & $70(60-130)$ & \multirow[t]{2}{*}{$<0,01$} \\
\hline & $\mathrm{O} \pm \mathrm{SD}$ & $88,8 \pm 17,5$ & $81,5 \pm 21,2$ & \\
\hline \multicolumn{5}{|c|}{ EŞLİK EDEN SEMPTOMLAR } \\
\hline \multirow[t]{2}{*}{ Bulantı kusma } & $\operatorname{Var}(\mathrm{n}=159 ; \% 79,59)$ & $86(\% 82,7)$ & $73(\% 76,0)$ & \multirow[t]{2}{*}{$>0,05$} \\
\hline & Yok $(n=41, \% 20,5)$ & $18(\% 17,3)$ & $23(\% 24,0)$ & \\
\hline \multirow[t]{2}{*}{ Kabızlık } & $\operatorname{Var}(n=42, \% 21,0)$ & $28(\% 26,9)$ & $14(\% 14,6)$ & \multirow[t]{2}{*}{$<0,05$} \\
\hline & Yok $(\mathrm{n}=158, \% 79,0)$ & $76(\% 73,1)$ & $82(\% 85,4)$ & \\
\hline \multirow[t]{2}{*}{ İshal } & $\operatorname{Var}(\mathrm{n}=17, \% 8,5$ & $7(\% 6,7)$ & $10(\% 10,4)$ & \multirow[t]{2}{*}{$>0,05$} \\
\hline & Yok $(\mathrm{n}=183, \% 91,5)$ & $97(\% 93,3)$ & $86(\% 89,6)$ & \\
\hline \multirow{2}{*}{$\begin{array}{l}\text { Üriner sistem şikayetle- } \\
\text { ri }\end{array}$} & $\operatorname{Var}(\mathrm{n}=29 ; \% 30,2)$ & $0(\% 0)$ & $29(\% 30,2)$ & \multirow[t]{2}{*}{$<\mathbf{0 , 0 0 1}$} \\
\hline & Yok $(\mathrm{n}=171 ; \% 69,8)$ & $104(\% 100)$ & $67(\% 69,8)$ & \\
\hline \multicolumn{5}{|c|}{ ÖZGEÇMIŞ̧ } \\
\hline \multirow{2}{*}{$\begin{array}{l}\text { Geçirilmiş batın cerrahi } \\
\text { öyküsü }\end{array}$} & $\operatorname{Var}(\mathrm{n}=61, \% 30,5)$ & $42(\% 40,4)$ & $19(\% 19,8)$ & \multirow[t]{2}{*}{$<0,05$} \\
\hline & Yok $(\mathrm{n}=139, \% 69,5)$ & $62(59,6)$ & $77(\% 80,2)$ & \\
\hline \multirow{4}{*}{$\begin{array}{l}\text { MUAYENE BULGU- } \\
\text { LARI }\end{array}$} & Hassasiyet $(n=90, \% 45,0)$ & $28(\% 31,0)$ & $62(\% 69,0)$ & $<\mathbf{0 , 0 5}$ \\
\hline & Hassasiyet+defans $(\mathrm{n}=41, \% 20,5)$ & $25(\% 61,0)$ & $16(\% 39,0)$ & $<0,05$ \\
\hline & Hassasiyet+rebound $(\mathrm{n}=17, \% 8,5)$ & $8(\% 47,1)$ & $9(\% 52,9)$ & $>0,05$ \\
\hline & Hassasiyet + defans + rebound $(n=52, \% 26,0)$ & $43(\% 82,7)$ & $9(\% 9,4)$ & $<\mathbf{0 , 0 5}$ \\
\hline & LABORATUAR & & & \\
\hline $\begin{array}{l}\text { Beyaz küre sayısı bin/ } \\
\text { UL }\end{array}$ & Ortanca (min-max) & $\begin{array}{c}14,65(7,9- \\
29,8)\end{array}$ & $\begin{array}{l}12,9(5,8- \\
18,3)\end{array}$ & $<0,001$ \\
\hline & $\mathrm{O} \pm \mathrm{SD}$ & $15,27 \pm 4,10$ & $12,18 \pm 2,82$ & \\
\hline
\end{tabular}

CNKA: Cerrahi nedenli karın ağnıları; CNOKA: Cerrahi nedenli olmayan karın ağrıları . 
Tablo 3. CNKA ve CNOKA'larında istenilen tetkik, konsültasyon, AS takip süresi, maliyet, ve hastaların AS akıbetlerinin dağılımı.

\begin{tabular}{|c|c|c|c|c|}
\hline & & $\begin{array}{c}\text { CNKA } \\
(\mathrm{n}=104, \% 52,0)\end{array}$ & $\begin{array}{c}\text { CNOKA } \\
(\mathrm{n}=96, \% 48,0)\end{array}$ & $p$ \\
\hline \multicolumn{5}{|c|}{ İSTENILLEN GÖRÜNTÜLEME YÖNTEMLERİ } \\
\hline İstenmemiş & $\mathrm{n}=4, \% 2,0$ & 0 & $4, \% 4,2$ & \multirow[t]{6}{*}{$<0,05$} \\
\hline Sadece DG & $\mathrm{n}=50, \% 25,0$ & $15, \% 14,4$ & $35, \% 36,5$ & \\
\hline Sadece USG & $\mathrm{n}=11, \% 5,5$ & $3, \% 2,9$ & $8, \% 8,3$ & \\
\hline DG+USG & $\mathrm{n}=81, \% 40,5$ & $55, \% 52,9$ & $26, \% 27,1$ & \\
\hline DG+BT & $\mathrm{n}=5, \% 2,5$ & $4, \% 3,8$ & $1, \% 1,0$ & \\
\hline DG+USG+BT & $\mathrm{n}=49, \% 24,5$ & $27, \% 26,0$ & $22, \% 22,9$ & \\
\hline \multicolumn{5}{|l|}{ KONSULTASYON } \\
\hline İstendi & $\mathrm{n}=141, \% 70,5$ & $103, \% 99,0$ & $38, \% 39,6$ & \multirow[t]{2}{*}{$<0,001$} \\
\hline İstenmedi & $\mathrm{n}=59, \% 29,5$ & $1, \% 1,0$ & $58, \% 60,4$ & \\
\hline \multicolumn{5}{|c|}{ ACIL SERVIS TAKİP SÜRESİ (Saat) } \\
\hline \multicolumn{2}{|l|}{ Ortanca (min-max) } & $6(1-72)$ & $5,5(1-72)$ & \multirow[t]{2}{*}{$<0,05$} \\
\hline \multicolumn{2}{|l|}{$\mathbf{O} \pm \mathbf{S D}$} & $9,5 \pm 10,9$ & $8,0 \pm 11,2$ & \\
\hline \multicolumn{5}{|c|}{ TOPLAM MALIYET (TL) } \\
\hline \multicolumn{2}{|l|}{ Ortanca (min-max) } & $77,8(50,5-395,0)$ & $58,9(0-356,0)$ & \multirow[t]{2}{*}{$<0,05$} \\
\hline \multicolumn{2}{|l|}{$\mathbf{O} \pm \mathbf{S D}$} & $132,7 \pm 106,0$ & $95,7 \pm 89,1$ & \\
\hline \multicolumn{5}{|c|}{ YAŞ GRUPLARINA GÖRE MALİYET DAĞILIMI } \\
\hline \multirow[t]{2}{*}{ 16-25 } & Ortanca (min-max) & $204,9(67,3-346,1)$ & $46,4(0-227,8)$ & \multirow[t]{2}{*}{$<0,05$} \\
\hline & $\mathrm{O} \pm \mathrm{SD}$ & $188,3 \pm 123,8$ & $265,2 \pm 64,2$ & \\
\hline \multirow[t]{2}{*}{ 26-35 } & Ortanca (min-max) & $62,3(52,9-202,2)$ & $58,3(31,1-202,2)$ & \multirow[t]{2}{*}{$>0,05$} \\
\hline & $\mathrm{O} \pm \mathrm{SD}$ & $82,9 \pm 50,0$ & $69,2 \pm 49,9$ & \\
\hline \multirow[t]{2}{*}{$36-45$} & Ortanca (min-max) & $70,6(50,5-329,3)$ & $57,2(3,9-326,3)$ & \multirow[t]{2}{*}{$>0,05$} \\
\hline & $\mathrm{O} \pm \mathrm{SD}$ & $105,4 \pm 87,1$ & $100,3 \pm 107,6$ & \\
\hline \multirow[t]{2}{*}{$46-55$} & Ortanca (min-max) & $84,2(60,5-350,0)$ & $67,2(19,9-356,6)$ & \multirow[t]{2}{*}{$>0,05$} \\
\hline & $\mathrm{O} \pm \mathrm{SD}$ & $135,0 \pm 103,6$ & $102,1 \pm 105,6$ & \\
\hline \multirow[t]{2}{*}{$56-65$} & Ortanca (min-max) & $84,2(59,0-395,0)$ & $71,2(6,6-208,7)$ & \multirow[t]{2}{*}{$>0,05$} \\
\hline & $\mathrm{O} \pm \mathrm{SD}$ & $143,1 \pm 115,5$ & $103,7 \pm 82,4$ & \\
\hline \multirow[t]{2}{*}{$66-75$} & Ortanca (min-max) & $89,3(59,0-391,9)$ & $99,5(19,9-225,9)$ & \multirow[t]{2}{*}{$>0,05$} \\
\hline & $\mathrm{O} \pm \mathrm{SD}$ & $146,3 \pm 116,0$ & $123,5 \pm 80,4$ & \\
\hline$>75$ & Ortanca (min-max) & $70,0(50,5-366,1)$ & $205,3(48,1-356,6)$ & $>0,05$ \\
\hline & $\mathrm{O} \pm \mathrm{SD}$ & $124,7 \pm 107,7$ & $186,0 \pm 131,7$ & \\
\hline & ACÍL S & VISS AKIBETLERI & & \\
\hline Yatış & $\mathrm{n}=88(\% 44,0)$ & $71(\% 68,3)$ & $17(\% 17,7)$ & \\
\hline Sevk & $\mathrm{n}=32(\% 16,0)$ & $24(\% 23,1)$ & $8(\% 8,3)$ & \\
\hline Önerilerle taburcu & $\mathrm{n}=69(\% 34,5)$ & $3(\% 2,9)$ & $16(\% 68,8)$ & \\
\hline Tedavi red & $\mathrm{n}=8(\% 4,0)$ & $3(\% 2,9)$ & $5(\% 5,2)$ & \\
\hline Eksitus & $\mathrm{n}=3(\% 1,5)$ & $3(\% 2,9)$ & 0 & \\
\hline $\begin{array}{l}\text { AS'te kalış süresi } \\
\text { (saat) }\end{array}$ & Konsultasyon İsten & Hastalar $(n=141)$ & $\begin{array}{l}\text { Konsultasyon İsten- } \\
\text { meyen Hastalar } \\
(\mathrm{n}=59)\end{array}$ & $p$ \\
\hline Ortanca (min-max) & & & $4(1-12)$ & $<0,001$ \\
\hline $\mathrm{O} \pm \mathrm{SD}$ & 10 , & 2,6 & $4,6 \pm 2,2$ & \\
\hline Toplam maliyet (TI & & & & \\
\hline Ortanca (min-max) & $84,2(5$ & $-395,0)$ & $38,6(0-311,9)$ & $<0,001$ \\
\hline $\mathrm{O} \pm \mathrm{SD}$ & 141 , & 03,8 & $50,8 \pm 46,6$ & \\
\hline
\end{tabular}

CNKA: Cerrahi nedenli karın ağrıları; CNOKA: Cerrahi nedenli olmayan karın ağrıları; DG; Direk Grafi; USG: Ultrasonografi; BT:Bilgisayarlı Tomografi; TL: Türk Lirası; AS: Acil Servis. 
Tablo 4. CNKA ve CNOKA olgularda son tanıya göre AS’te kalış süresi ve maliyet dağılımı.

\begin{tabular}{|c|c|c|c|c|c|}
\hline \multirow[b]{2}{*}{ CNKA } & \multirow{2}{*}{$\begin{array}{c}\text { Hasta Sayısı } \\
104\end{array}$} & \multicolumn{2}{|c|}{ Süre (saat) } & \multicolumn{2}{|c|}{ Maliyet (TL) } \\
\hline & & $\begin{array}{c}\text { Ortanca } \\
(\min -\mathbf{m a x})\end{array}$ & $\mathbf{O} \pm \mathbf{S D}$ & $\begin{array}{c}\text { Ortanca } \\
(\min -\mathbf{m a x})\end{array}$ & $\mathbf{O} \pm \mathbf{S D}$ \\
\hline Mekanik Obstrüksiyon & 35 & $6(3-72)$ & $11,9 \pm 16,7$ & $67,3(50,5-350,0)$ & $102,8 \pm 88,1$ \\
\hline Akut Kolesistit & 30 & $7(2-26)$ & $9,0 \pm 6,4$ & $65,6(55,4-395,0)$ & $125,4 \pm 92,4$ \\
\hline Akut Apandisit & 20 & $6(2-24)$ & $8,0 \pm 4,7$ & $72,6(52,9-345,0)$ & $117,3 \pm 90,2$ \\
\hline Perforasyon & 10 & $7(1-9)$ & $6,0 \pm 2,4$ & $312,5(59,0-350,0)$ & $220,4 \pm 141,7$ \\
\hline Mesenter İskemi & 4 & $16(2-25)$ & $14,8 \pm 12,0$ & $\begin{array}{c}360,7(111,7- \\
391,9)\end{array}$ & $306,3 \pm 130,8$ \\
\hline Cerrahi Jinekolojik patoloji & 4 & $6(4-6)$ & $5,5 \pm 1,0$ & $90,6(83,8-202,2)$ & $116,8 \pm 57,1$ \\
\hline $\begin{array}{l}\text { Abdominal Aort } \\
\text { Diseksiyonu }\end{array}$ & 1 & 4 & & 331,6 & \\
\hline CNOKA & 96 & & & & \\
\hline Ürolitiyazis & 27 & $4(1-16)$ & $5,1 \pm 2,7$ & $45,4(0-129,5)$ & $55,7 \pm 56,74$ \\
\hline NSKA & 19 & $6(1-72)$ & $15,6 \pm 22,2$ & $80,1(52,0-356,6)$ & $131,6 \pm 97,0$ \\
\hline Pankreatit & 18 & $8(3-24)$ & $10,6 \pm 6,8$ & $202,2(54,4-35,6)$ & $189,4 \pm 79,5$ \\
\hline Üriner Sistem Enfeksiyonu & 9 & $4(2-10)$ & $4,7 \pm 2,5$ & $37,6(6,6-90,3)$ & $42,8 \pm 24,1$ \\
\hline Konstipasyon & 7 & $4(1-16)$ & $3,9 \pm 2,0$ & $45,4(11,8-78,7)$ & $43,8 \pm 20,5$ \\
\hline Dispepsi & 5 & $4(1-6)$ & $3,6 \pm 1,8$ & $45,4(0-129,5)$ & $49,3 \pm 45,4$ \\
\hline Gastroenterit & 5 & $5(3-8)$ & $5,2 \pm 1,9$ & $19,9(3,9-311,9)$ & $75,6 \pm 132,3$ \\
\hline Jinekolojik Patoloji & 3 & $4(4-8)$ & $5,3 \pm 2,3$ & $58,3(32,0-64,9)$ & $51,8 \pm 17,4$ \\
\hline Biliyer Kolik & 2 & $5(4-5)$ & $4,5 \pm 1,3$ & $\begin{array}{c}201,3(65,6- \\
201,3)\end{array}$ & $135,4 \pm 75,4$ \\
\hline FMF & 1 & 5 & & 32,0 & \\
\hline
\end{tabular}

CNKA: Cerrahi nedenli karın ağrıları; CNOKA: Cerrahi nedenli olmayan karın ağrıları; TL: Türk Lirası; FMF: Ailevi Akdeniz Ateşi Servis. 

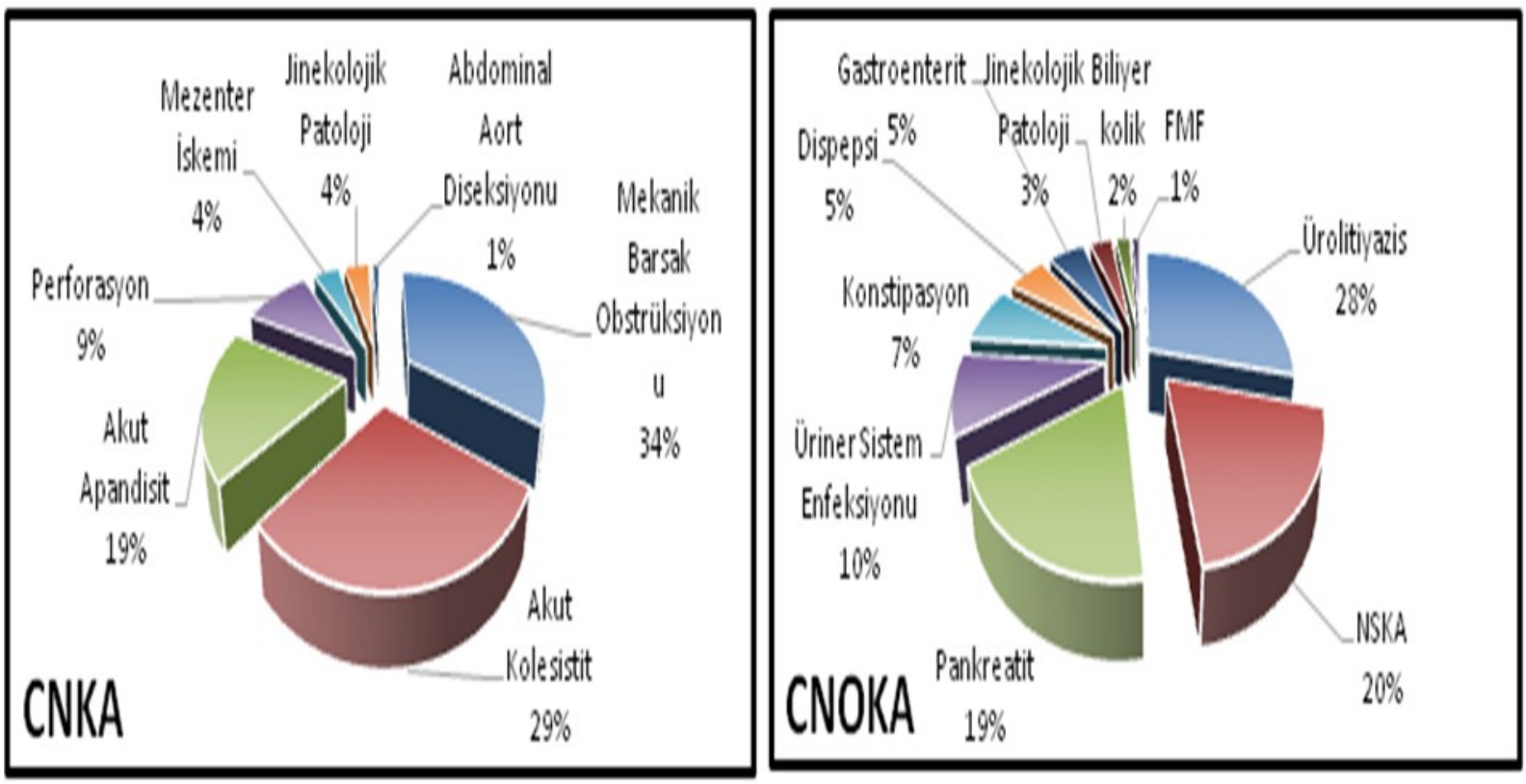

Şekil 1. Cerrahi nedenli karın ağrıları (CNKA) ve cerrahi nedenli olmayan karın ağrıları'nın (CNOKA) sıklık dağılımı. 